ELORE (ISSN 1456-3010), vol. 20 - 2/2013.

Julkaisija: Suomen Kansantietouden Tutkijain Seura ry.

[http://www.elore.fi/arkisto/2_13/kajander.pdf]

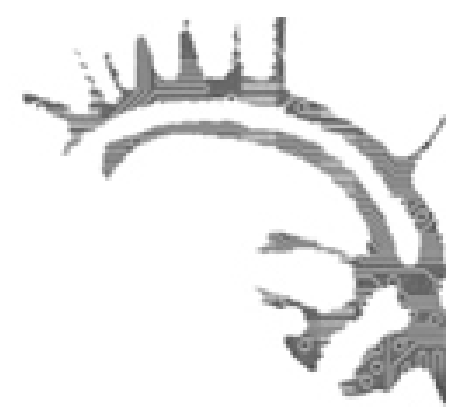

Katsaus

\title{
MITÄ ANNETTAVAA FILOSOFISELLA HERMENEUTIIKALLA ON ETNOLOGIALLE?
}

\author{
$\underline{\text { Konsta Kajander }}$
}

Kun kansatieteen apulaisprofessori Veikko Anttila kirjoitti lähes 30 vuotta sitten tieteenalansa teoreettisista lähtökohdista ja paradigmasta, hän jakoi kansatieteen tutkimusotteet kausaalis-positivistisiin eli selittäviin ja fenomenologis-hermeneuttisiin eli ymmärtäviin (Anttila 1985, 21). Myöhemmistä oppikirjoista huomataan, kuinka etnologisen tutkimuksen painopiste on muuttunut totuutta tavoittelevasta positivismista kohti hermeneuttista kulttuurianalyysiä, objektiivisesta ja faktuaalisesta maailmasta merkitysten tutkimukseen (Ruotsala 2005, 46-47; Sääskilahti 1999, 152). Kehityskulkuun liittyy olennaisesti myös refleksiivinen käänne, jonka myötä tutkimuskohdetta ei ole enää ajateltu ulkoapäin tarkasteltavaksi objektiksi, vaan tutkimustulosten on nähty syntyvän dialogisessa vuoropuhelussa tutkijan ja tutkittavan sekä nykyisyyden ja menneisyyden välillä (Kirveennummi 1997, 43; Vasenkari \& Pekkala 2000). Etnologia vaikuttaisikin olevan paradigmaattisesti fenomenologis-hermeneuttis-refleksiivisessä vaiheessa, jonka vaihtoehtona ei enää ole niinkään positivistinen vaan kriittis-emansipatoris-refleksiivinen tutkimusote. Se ilmenee kiinnostuksena muun muassa etnisyyteen, vähemmistöihin, identiteetteihin, sukupuoleen ja ruumiillisuuteen liittyviin kysymyksiin.

Hermeneutiikkaa käytetään monissa ihmistieteissä jopa "muotifilosofiana", mutta kuten filosofi Erna Oesch on huomauttanut, usein varsin epämääräisellä tavalla. "Aina ei ole selvää, mistä puhutaan, kun puhutaan hermeneutiikasta." (Oesch 2005, 13.) ${ }^{1}$ Koska hermeneutiikka pitää sisällään erilaisia suuntauksia ja sovelluksia, jotka vaihtelevat Wilhelm Diltheyn metodikysymyksistä Jürgen Habermasin yhteiskuntakriittiseen 
hermeneutiikkaan ja Emilio Bettin juridisesta hermeneutiikasta Rudolf Bultmannin teologiaan, pelkkä viittaaminen lähestymistavan hermeneuttisuuteen ei riitä, vaan tutkijan on määriteltävä tarkemmin, mihin traditioon hän itsensä sijoittaa.

Hahmottelen artikkelissani filosofisen hermeneutiikan ja etnologian mahdollisia yhteyksiä. Aluksi johdattelen aiheeseen avaamalla filosofisen hermeneutiikan oppihistoriaa ja sen tärkeimpien hahmojen, Martin Heideggerin ja Hans-Georg Gadamerin ajatuksia. Tämän jälkeen sovellan Heideggerin käsitteitä etnologiseen esinetutkimukseen sekä esitän Gadameriin tukeutuvan tulkinnan emic-etic -aspekteista ymmärtämisen horisontteina. Pohdittuani hermeneuttisesta näkökulmasta etnologista tutkimusprosessia arvauksista arviointiin esittelen vielä lopuksi kriittisiä huomioita hermeneutiikkaan perustavan ymmärtävän lähestymistavan rajoituksista ja sen vaihtoehdoista. Kirjoituksellani on kaksi tavoitetta. Aihetta aiemmin tuntemattomalle tarjoan artikkelillani lyhyen johdatuksen filosofisen hermeneutiikan mahdollisuuksiin etnologiassa. Pidemmälle ehtineille artikkelini voi puolestaan toimia kipinänä etnologian tieteenfilosofiseen pohdintaan, tietoteoreettisten premissien avaamiseen ja vaihtoehtoisten tiedonintressien esittelyyn.

\section{FILOSOFINEN HERMENEUTIIKKA - TULKINTATIETEESTÄ OLEMISEN KYSYMYKSEKSI}

Filosofisen hermeneutiikan tarkastelu on luonteva aloittaa 1800-luvun saksalaisesta romantiikasta ja historismista, sillä näiden piirissä harjoitetusta August Comten ja John Stuart Millin positivistisen tieteenfilosofian kritiikistä alkoi edelleenkin voimassa oleva debatti luonnon- ja ihmistieteiden erityispiirteistä. Erna Oeschin mukaan Friedrich Schleiermacher alkoi puhua ensimmäisenä hermeneutiikasta yleisenä ymmärtämistä koskevana tieteenä, jonka tehtävänä on vastata kysymykseen, miten ymmärtäminen on ylipäätään mahdollista. Näin Schleiermacher muodosti pohjan Diltheyn ymmärtämisen analyysille ja edelleen Heideggerin ja Gadamerin filosofioille. (Oesch 2005, 30-31.) Wilhelm Dilthey kritisoi positivismin ajatusta tieteiden ykseydestä ja jakoi tieteet selittäviin luonnontieteisiin ja ymmärtäviin hengentieteisiin. Ero oli Diltheyn mukaan siinä, että luonnontieteissä on mahdollista tutkia ulkoista maailmaa, kun taas ihmistieteissä ymmärrys tapahtuu sisäisestä kokemuksesta käsin. Eri aikakaudet ja yhteiskunnat eroavat toisistaan ja representoivat maailman omista lähtökohdistaan eri tavalla. Dilthey ajatteli, että eri tieteenalat tarvitsevat omat menetelmänsä ja ettei ihmistieteissä voida tutkia faktoja samalla tavalla kuin luonnontieteissä. (Dilthey 1989, 60-61, 80-81, 168-169.)

Martin Heideggerin opettaja, fenomenologian isäksikin kutsuttu Edmund Husserl, irtaantui Diltheyn historismista, joka Juha Varton mukaan kielsi objektiiviset merkitykset ja teki tiedosta aikasidonnaista. Husserlille historiallisuus oli kyllä sinänsä olemassa: merkitykset ovat syntyneet ajassa, mutta ne voivat sisältää jotakin muuttumatonta. (Varto 2005, 47.) Sen sijaan Husserl kehitteli omaa fenomenologiseen reduktioon perustuvaa oppia, jossa havainto, "asioihin itseensä katsominen", voitaisiin saavuttaa puhtaasti ilman arkipäivän ei-teoreettisten intressien vaikutusta. Husserl uskoi oppinsa avulla löytäneensä ennakkoluuloista vapaan "ankaran" filosofian. (Kusch 1986, 77-78.) 
Heideggerin vastaus Husserlille tuli hänen teoksessaan Sein und Zeit (1927, Oleminen ja aika, 2000), jonka erityinen merkitys hermeneutiikalle oli niin kutsutun ontologisen käänteen tuominen teorianmuodostukseen. Heideggerille ymmärtäminen ei merkinnyt metodia tai tekstin tulkintaa vaan ihmisen maailmassa olemisen tapaa. Tulkitseva ymmärtäminen on näin ollen ontologinen tapahtuma. Hän kutsuu tulkitsevan subjektin olemista, "tätä olevaa, joka me aina olemme ja jonka olemismahdollisuudet sisältävät kyvyn kysyä", termillä Dasein eli täällä-olo. (Heidegger 2000, 27.) Heidegger huomauttaa, että ymmärtäminen kuuluu osaksi ihmisen mielen rakennetta, jossa ymmärtäminen saa kehämäisen ja eksistentiaalisen esirakenteen. Tämä merkitsee samalla sitä, että tulkitsijan esiymmärrys kulkee mukana tulkinnoissa ja vaikuttaa niihin. Tulkitsijan ei kuitenkaan Heideggerin mukaan pidäkään yrittää kehästä ulos vaan etsiä oikeaa tapaa tulla kehään jossa hän toisaalta jo maailmassa olemassa olevana valmiiksi on. Ymmärtämistä voidaan edistää pyrkimällä pohtimaan ja välttämään etukäteen erehtymistä "niiden olemuksellisten ehtojen suhteen, joiden varassa tulkitseminen tapahtuu". (Heidegger 2000, 197.)

Heideggerin oppilas Hans-Georg Gadamer toi merkittävän panoksensa hermeneutiikkaan pääteoksessaan Warheit und Methode (1960, Truth and Method, 1988). Heideggerin tavoin ymmärtäminen ei merkinnyt Gadamerille metodia, jolla merkitykset tulkitaan oikein eikä liiemmin kahden ihmisen "sielujen yhteenkietoutumista". Sen sijaan ymmärtäminen syntyy toisen ihmisen tai tekstin kanssa käytävässä keskustelussa, jossa pyritään yhteisen merkityksen löytämiseen ja horisonttien yhteensulautumiseen. (Gadamer 1988, 260-261, 273.) Horisontin Gadamer määrittelee "näkökentäksi, johon sisältyy ja rajoittuu kaikki mikä on näkyvissä jostakin paikasta." Horisontti on kytköksissä situaatioon eli historialliseen tilanteeseen, traditioon, johon yksilö syntyy ja jossa hän elää, ja se sisältää ympäristön, joka rajaa näkemisen mahdollisuuksia. (Gadamer 1988, 269.) Vaikka Gadamer korostaa ymmärtämisen vaikutushistoriallista luonnetta ja yksilön traditioon kiinnittymisen välttämättömyyttä, hän ei pidä horisonttia staattisena. Se ei eristä kulttuuria muutoksilta, vaan niin nykyisyyden kuin menneisyyden horisontit liikkuvat yksilöiden ja tradition mukana. (Gadamer 1988, 270.)

Filosofisen hermeneutiikan soveltaminen käytännön tutkimukseen on erittäin haastavaa. Vaarana on, että teoreettiset ajatukset ja käsitteet jäävät lähinnä sivuhuomautuksiksi eivätkä jäsennä millään tavalla itse aineistoanalyysiä. Erityisen hankalaa tämä on Martin Heideggerin filosofian kohdalla. Psykologi Lauri Rauhala on huomauttanut, että Heideggerin "syväontologiaa on vaikea liittää tutkimusta palvelevalla tavalla reaaliontologiaan", sillä "syväontologia ei yksin voi olla riittävä empiiristen tieteiden ontologiaksi" (Rauhala 2005, 127). Onkin syytä muistuttaa, että Heideggerin olemisen kysymys ja Gadamerin ymmärtämiseen ja tulkintaan liittyvät kysymykset ovat luonteeltaan ensisijaisesti filosofisia. Seuraavassa osoitan, miten heidän ajattelunsa voi avata näkökulmia etnologiseen tutkimukseen. 
Konsta Kajander: Mitä annettavaa filosofisella hermeneutiikalla on etnologialle?

\section{Heidegger JA ESINEET}

Kritisoidessaan Husserlia olemisen eri merkitysten huomiotta jättämisestä Heidegger esitteli kolme käsitettä, käsillä-oleva, esillä-oleva ja eksistenssi (Kusch 1986, 77; vrt. Kakkori 2012, 213-216), joiden avulla voidaan hahmottaa ihmisten esinesuhteiden merkitysten muuttuvaa liikettä matkalla esineen tekovaiheesta esineen käyttöön. Pelkkänä käsillä-olevana välineenä esine on vielä huomaamaton käyttöesine, osa arkista toimintaa. Ihmisen ympäristö tuo esineen esillä-olevaksi lisäämällä siihen arvottavat merkitykset mukaan. Välineellisestä käyttöesineestä tulee esine, jolla on kulttuurista arvoa kuten kauneus, rumuus, sopivuus, sopimattomuus, käyttökelpoisuus ja käyttökelvottomuus. Heidegger huomauttaa, että pelkkään ulkonäköön suuntautuva teoreettinen katse ei voi päästä esineen käsillä-olevuuteen eli esineen käyttöön. Käsillä-olevuutta voi kuitenkin "olla" vain esillä-olevuuden perusteella. Esineet ovat näin ollen jo esitulkittuja ennen yksilön henkilökohtaista suhdetta niihin. (Heidegger 2000, 66, 97, 100-101, 132-133.)

Jos esine koetaan yksilöllisesti tärkeänä, sen merkityskenttä laajenee käyttäjänsä eksistenssiin. Tällöin esineen merkitys ei perustu pelkästään ulkoa annettuihin objektivoituihin merkityksiin, vaan siitä tulee osa yksilön minuutta ja omaa elämää. Esimerkiksi levy- tai kirja-kokoelma ei ole vain kasa esineitä, vaan ne kertovat kokoajansa elämästä ja muistoista. Näin esineen viittaussuhde laajenee esineen käyttäjään. Eksistenssi viittaa kuitenkin samalla työn valmistajaan. "Työ on veistetty häneen, hän "on" työn synnyssä läsnä. Tämä konstitutiivinen viittaus ei puutu edes tusinatavaran valmistuksesta. Siinä viittaus on vain määrittämätön ja osoittaa mielivaltaiseen, tavanomaiseen." (Heidegger 2000, 99.) Vaikka esine olisi taide-esineen sijasta massatuotantoon valmistettu kulutustuote, myös esineen valmistajat, tehtaan työntekijät, ovat jättäneet siihen merkin. Pelkkä yksittäisen esineen tarkastelu ei kuitenkaan riitä, vaan se on asetettava yksittäisen tekstin tavoin konteksteihin, kokonaisuuksiin, joiden osia ne ovat (Glassie 1999, 47). Heidegger kutsuu tätä termillä välinekokonaisuus. "Tarkkaan ottaen koskaan ei 'ole' yhtä välinettä. Välineen olemiseen kuuluu aina välinekokonaisuus, jossa se voi olla se väline, mikä se on. [..] Välineellisyyttään vastaten väline aina on yhteenkuuluvuudestaan toiseen välineeseen." (Heidegger 2000, 96-97.)

Otetaan esimerkkinä levyjen kuuntelu- ja keräilyharrastus. Vaikka harrastaja pitäisi vinyyliä parhaana mahdollisena musiikkiformaattina, pelkkä hyväkuntoinen levy ei takaa hyvää lopputulosta, vaan esimerkiksi levysoitin, levylautanen, äänivarsi, äänirasia, neula, stereot, kaiuttimet, virtalähde sekä huoneen akustiikka vaikuttavat oleellisesti kuuntelukokemukseen. Yksikin viallinen komponentti vinyylin, levysoittimen ja äänentoiston muodostamassa välinekokonaisuudessa heikentää äänenlaatua ja pahimmassa tapauksessa estää kuuntelun kokonaan. (Kajander 2012, 79.) Lisäksi levykokoelma tarvitsee ympärilleen levyhyllyn ja huoneiston, ja toisaalta levyjen keräileminen ja ostaminen tapahtuu oman välinekokonaisuuden eli levykaupan puitteissa. Näin harrastus toimii useilla esineellisten välikokonaisuuksien tasoilla, jotka on syytä ottaa huomioon ilmiön kokonaisvaltaisessa tarkastelussa. Esineen elinkaarta ja historiaa voisi hahmottaa myös tutkimalla esineen luomista, kommunikointia ja käyttöä folkloristi Henry Glassien ehdotuksen mukaisesti (Glassie 1999, 48). Näin analyysiin saataisiin mukaan niin 
esineen tekijöiden intentioita, kulttuurista vastaanottoa sekä esineen käyttäjien omia merkityksen antoja.

\section{EMIC JA ETIC YMMÄRTÄMISEN HORISONTTEINA}

Yksi ymmärtävään lähestymistapaan perustuvan etnologisen tutkimuksen lähtöoletuksista on, että tutkimustieto muodostuu vuorovaikutuksessa tutkittavien kanssa. Mutta mitä vuorovaikutustilanteessa oikeastaan tapahtuu ja ketkä siinä kohtaavat? Tätä ongelmaa voidaan lähestyä kulttuurintutkijoille tutun emic-etic-vastakkainasettelun kautta, jota seuraavassa demonstroin kahdella laatimallani kuviolla (Kajander 2012, 16). Kun tutkija ja tutkittava kohtaavat, kyse ei ole ainoastaan kahden yksilön kohtaamisesta. Yksilöön vaikuttavat joko tiedostetusti tai tiedostamatta sen yhteisön käsitteet ja ajattelutavat, johon hän on kasvanut ja sosiaalistunut. Jos lähtökohdaksi otetaan tutkittavan kulttuurin jäsenen ja tiedeyhteisön jäsenen kohtaaminen, on kyseessä siis sekä kahden yksilön (pienemmät ympyrät) että emic- ja etic-yhteisön (suuremmat ympyrät) horisonttien kohtaamisesta, joiden välillä ymmärtäminen tapahtuu (keskellä oleva alue) (Kuvio 1, vas.). Kulttuuritieteellinen esitystapa, tutkimusraportointi, edellyttääkin tässä jaottelussa tutkimuksen tekijältä etic-aspektin omaksumista, sillä muuten tutkimus jäisi kuvaukseksi (emic-description), ei analyysiksi (etic-analysis).
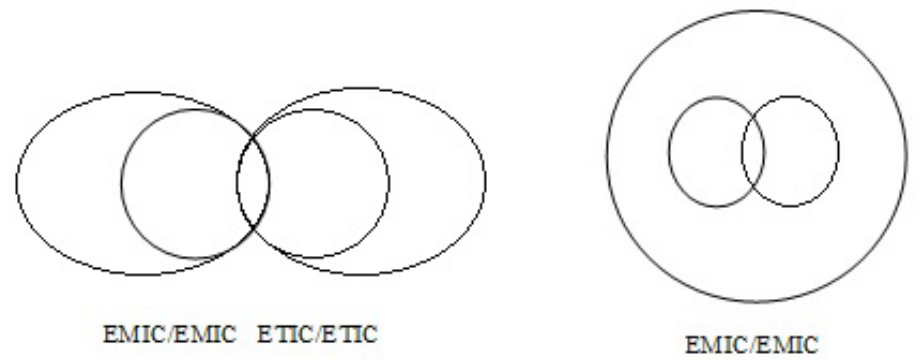

EMIC/ETIC-horisonttien (vas.) ja EMIC/EMIC-horisonttien (oik.) kohtaaminen.

Mutta entä jos tutkija kuvaakin itselleen jo ennalta tuttua kulttuuri-ilmiötä ja yhteisöä? Ongelma tuli eteeni pro gradua tehdessä, sillä tutkin musiikkiharrastajia ja levyjen keräilijöitä itsekin musiikinharrastajana ja levyjen keräilijänä. Tutkimuksen tekeminen merkitsi näin ollen sitä, että tutkimusaspektini oli osaksi emisistinen. Omaa ymmärrystäni helpotti, että kaikki haastateltavat olivat suomalaisia, joten he jakoivat kanssani yhteisen kielen lisäksi (joitakin) samoja kulttuurillisia arvoja ja normeja. Toiseksi jaoimme samankaltaisen harrastuksen ja siihen liittyvän kielen, johon sisältyi jaettua tietoa muun muassa musiikin historiasta, musiikkitermeistä ja äänentallennusformaateista. Näin ollen kohtaamiseni tutkimuskentällä haastateltavien kanssa tapahtui musiikinharrastajien yhteisön kollektiivisen horisontin sisällä (Kuvio 1, oik.).

Charlotte Aull Davies on kuitenkin huomauttanut, että tutkijan kanssa samaa kulttuuria edustavat haastateltavat eivät välttämättä jaa haastattelijan näkökulmia, ja että pyrkivät torjumaan tai määrittelemään uudelleen haastattelijan termejä. Tutkijoiden 
onkin Davisin mukaan pyrittävä laajentamaan kontekstiaan etäännyttämisen avulla, vertailevalla lukutavalla, toisenlaisten sosiaalisten ja kulttuuristen muotojen rinnakkaisasettelulla ja problematisoinnilla. (Davies 1999, 108.) Juuri tästä syystä etnologinen esine- ja keräilytutkimus toimi tärkeänä vertailukohtana haastateltavieni mielipiteille, vaikka kaikki heistä eivät keräilijän määritelmää hyväksyneetkään. Näin sain myös tarvittua etäisyyttä harrastuksestani. (Kajander 2012, 4-5, 17.)

Loppujen lopuksi tutkija on tulkitessaan samanaikaisesti tekemisissä usean yhteisön kanssa. Tutkijan on toisaalta välttämätöntä tulkita kulttuuria etic-horisontin puitteissa, mutta hän ei myöskään täysin kykene tulkitsevana subjektina hyppäämään ulos siitä kulttuurista, emic-horisontista, jossa hän elää ja johon hän on kasvanut. Harri Nyman onkin todennut kansatieteen väitöskirjansa menetelmäpohdinnoissa, aivan oikein, että tutkijan persoona, elämänkokemukset ja maailmankatsomus vaikuttavat tulkintojen taustalla. "Kysymys on hermeneuttisen lähestymistavan mukaisesta perusasetelmasta, eräänlaisesta sinän - tutkimuskohde - ja minän - tutkija - välisestä keskustelusta." (Nyman 2011, 55.) Kun tähän määrittelyyn lisätään vielä yksilöiden taustalla vaikuttavat yhteisöt, voidaan sanoa, että kulttuurintutkimus on sukkuloimista emic- ja etichorisonttien välillä, jonka onnistunut lopputulos on riippuvainen vuoropuhelusta sekä yksilöiden että kulttuuri- ja tiedeyhteisöjen kanssa.

\section{ARVAUKSISTA ARVIOINTIIN - HUOMIOTA ETNOLOGISEEN TUTKIMUSPROSESSIIN}

Vaikka merkitykset eivät ole pöydälle nostettavia esineitä, tämä ei merkitse, ettei ihmis- ja luonnontieteiden tieteellinen päättely voisi sisältää yhtäläisyyksiä. Myös hermeneuttisessa ja ymmärtävässä tutkimuksessa on mahdollista keksiä ja testata (tulkinta) hypoteeseja, joita vahvistetaan, hylätään tai korjataan havaintojen pohjalta. (Niiniluoto 1983, 174-176.) Tulkintahypoteesien keksimisessä voitaisiin hyödyntää aikaisempien tutkimustuloksien ja tieteenalan teoreettisen käsitteiden ohella omaa, aukikirjoitettua esiymmärrystä ja itsereflektiota. Näitä esikäsityksiä verrataan ja ennen kaikkea koetellaan kenttätyöstä saadun tutkimusaineiston kanssa. Näin myös itsereflektio saataisiin integroitua vahvemmin aineiston menetelmälliseen lukutapaan.

Esiymmärryksen täydellinen reflektointi ei ole mahdollista, eikä tarpeenkaan. Gadamer muistuttaa, että tulkitsija ei voi erotella etukäteen ymmärtämisen mahdollistavia ennakkoluuloja väärinkäsityksiin johtavista. Kulttuurintutkimuksessa ymmärtäminen kehittyy sekä kenttätöissä, että analyysivaiheessa, kun ihmisten tai tekstin kohtaaminen herättävät uusia kysymyksiä. Nimenomaan dialogissa ilmenevät ristiriidat tutkijan ja tutkittavan merkityshorisontin välillä vievät ymmärrystä eteenpäin. Jos näin ei tapahtuisi, tutkija tietäisi lopputuloksen etukäteen. Gadamer ei silti vaadi omien mielipiteiden hylkäämistä: merkitykset ilmenevät siksi, että niitä alunperinkin luetaan ennakko-oletuksin. Hän kuitenkin edellyttää, että niiden oikeutusta ja pätevyyttä tutkitaan, luonnostellaan ja ollaan valmiita muuttamaan. Ymmärtäminen edellyttää, että kohdattava horisontti hyväksytään omassa toiseudessaan. (Gadamer 1988, 263; Gadamer 2004, 32-34, 38; ks. myös Ollitervo 2012, 216-219.) 
Tulkinnat on kuitenkin osattava vielä perustella tiedeyhteisölle ja muulle yleisölle. Filosofisen hermeneutiikan kolmas merkittävä hahmo Paul Ricoeur on esittänyt Heideggerista ja Gadamerista poikkeavia, tulkinnan metodologista toimintaa puolustavia näkemyksiä. Hän kuvailee tulkinnan prosessia selittämisen ja ymmärtämisen dialektiikkana, jossa tutkimuskohteesta (tekstistä) esitettyjä arvauksia työstetään, kunnes niille voidaan antaa selityksiä paremman ymmärtämisen ansiosta. Vielä alussa ymmärrys on arvaus, lopussa siitä tulee käsittämisen kautta "ymmärtämisen sofistikoituneempi muoto, jota selittävät menetelmät tukevat." (Ricoeur 2000, 119.) Vaikka ymmärtävässä otteessa puhutaan tulkinnasta, se ei merkitse kaikkien tulkintojen samanarvoisuutta. Ricoeur huomauttaa, että teksti esittää rajoitetun määrän mahdollisia konstruktioita, jolloin (kilpailevan) "tulkinnan ei tule olla ainoastaan todennäköinen, vaan todennäköisempi kuin toinen tulkinta". Näin myös hermeneuttisiin tulkintoihin sisältyy tieteellisen kumoamisen mahdollisuus. (Ricoeur 2000, 125-126.) Tulkintojen arviointi edellyttää samalla tutkimusaineiston läpinäkyvyyttä. Tutkimuksen lukijan on pystyttävä seuraamaan tulkintojen kehittymistä aina arvauksista analyysiin ja hypoteeseista lopputuloksiin.

\section{RIITTÄÄKÖ YMMÄRRYS?}

Jarkko Tontti julisti Tulkinnasta toiseen -kirjan johdannossa viime vuosisadan filosofisten koulukuntien kilpailun päättyneen hermeneutiikan voittoon. Hän katsoi tämän johtuneen siitä, että hermeneutiikalla ei ollut lyhyitä kukoistuskausia, vaan se pystyi uudistumaan ja puhuttelemaan erityistieteitä tulkinnan ja ymmärtämisen peruskysymyksillään. (Tontti 2005, 7.) Mutta onko tämä "voitto” pysyvä vai odottaako seuraava haastaja jo kulman takana? Kansatieteilijä Juhani U. E. Lehtonen on muistuttanut, että tieteen historiassa muutokset ovat aiemminkin heilahdelleet "aaltoliikkeen tai spiraalin tavoin, jossa tunne ja järki vuorottelevat". Näitä vastapareja ovat olleet Lehtosen mukaan antiikin filosofien thymos ja logos, 1800-luvun valistus ja romantiikka sekä 1900-luvun kvantitatiivinen ja kvalitatiivinen lähestymistapa lähestymistapa, järkiperäinen positivismi ja tunnekylläinen hermeneutiikka. (Lehtonen 2005, 12.)

Yksi mahdollinen hermeneutiikan haastava tieteenfilosofinen suuntaus saattaisi olla kriittinen realismi. Sen merkittävä edustaja filosofi Roy Bhaskar myönsi, että sosiaalitieteissä voidaan käsitellä hermeneuttisen tradition mukaisesti esitulkittua todellisuutta ja hyväksyi metodologisen erilaisuuden luonnon- ja ihmistieteiden välillä. Hän ei kuitenkaan katsonut, ettei sosiaalisia objekteja, uskomuksia ja merkityksiä voitaisi tarkastella tieteellisesti, kausaalisesti ja lakeja etsien, vaikka ne ovatkin laadullisesti erilaisia luonnon objekteista. (Bhaskar 1979, 26-28.) Realistinen näkökanta merkitsee myös ihmisistä riippumattoman todellisuuden hyväksymistä, jolloin tarkastelu voidaan ulottaa sisäisten merkitysten ulkopuolelle teoreettisten mallien avulla. Suuntausta kannattava antropologi Charlotte Aull Davies on esittänyt, että kriittinen realismi tarjoaa filosofisen perustan refleksiiviseen etnografiaan perustuvalle tutkimustyölle. Refleksiivisyydellä tuetut hermeneuttiset kenttätyökuvaukset merkitykset saisivat tällöin rinnalleen teoreettisten abstraktioiden kautta rakenteellisia selityksiä. (Davies 1999, 17-25.) Suomessa yhteis- 
kuntatieteiden puolella on jo ehditty käydä keskustelua realismin mahdollisuuksista (ks. Kuusela \& Niiranen 2006). Missä vaiheessa on etnologien vuoro?

Vaikka kansa tietää, etnologienkin on syytä pohtia, missä määrin tutkittavien todellisuuden kuvailu riittää kulttuurien kokonaisvaltaiseen ymmärtämiseen. Naistutkija ja tieteenfilosofi Kristiina Rolin on muistuttanut, ettei pelkkä toiminnan tai sosiaalisen käytännön ymmärtäminen riitä selittämään, "miksi joku ihminen toimi niin kuin hän toimi (sen sijaan että olisi toiminut toisella tavalla) tai miksi ihmiset pitävät yllä jotain sosiaalista käytäntöä (sen sijaan että antaisivat sen hävitä)" (Rolin 2006, 114). Kognitiivista uskontotiedettä edustava Ilkka Pyysiäinen on puolestaan esittänyt aiheellista kritiikkiä tutkijan eläytymisen riittämättömyydestä. Tuloksia on kyettävä perustelemaan muullakin, kun tutkijan ensikädentiedolla tai kyvyllä "eläytyä" ja "ymmärtää". Muussa tapauksessa tieteellinen tutkimus ei eroa journalismista tai turismista. Pyysiäinen ei sinänsä vastusta merkitysten tutkimusta, mutta edellyttää, että se tehdään kurinalaisesti. (Pyysiäinen 2001.) Kognitiivisen ja hermeneuttisen lähestymistapojen yhdistäminen ei ole lainkaan poissuljettu vaihtoehto kulttuurintutkijoille. Tästä tuoreena esimerkkinä Merja Vileniuksen Uskonnon ja alkuperän tutkimuksen historiaa ja nykypäivää (Vilenius 2012), jossa käydään vuoropuhelua näiden suuntausten välillä.

\section{LOPUKSI}

Filosofisen hermeneutiikan kärkihahmojen Heideggerin ja Gadamerin ansioksi voidaan katsoa tulkitsijan oman vastuun korostaminen tulkintoja tehdessä. Tulkintaan vaikuttaa tutkijan persoona, historiallinen ajanjakso, tulkitsijan kulttuuri sekä tieteenala, jonka puitteissa tulkintoja tehdään. Niinpä myöskään etnologiseen tutkimukseen ei voi lähteä tabula rasa-tilanteesta eikä kentälle todellakaan mennä "mieli avoimena". Mitään täysin ennakkoluulotonta ja neutraalia tutkimusta ei ole, mutta tätä ei tarvitse ajatella negatiivisesti. Esikäsitykset edeltävät, ainakin aluksi ohjaavat ja ennen kaikkea mahdollistavat ymmärtämistä ja tulkintaa, ja siten myös tutkimuksen tekoa, mutta käsityksiä on myös mahdollista muuttaa tutkimuksen edetessä. Tutkimusprosessin läpinäkyvyyttä voidaan vahvistaa omien esikäsitysten reflektoinnilla ja niiden vaikutusten arvioinnilla. (Kajander 2012, 11, 18-19.)

Dialoginen vuorovaikutus tutkittavan kanssa, pyrkimys merkitysten ymmärtämiseen tai aineiston tulkitseminen "kulttuuritekstinä" ovat hyviä lähtökohtia, mutta ne eivät vielä sellaisenaan takaa etnologian hermeneuttisuutta. Oma teoreettinen perhe on toki tärkeä tunnistaa, ja sen perheenjäsenille voidaan antaa tunnustusta, mikäli heidän ajatuksensa ovat johtaneet tutkimustyön kannalta merkittäviin oivalluksiin. Hermeneuttista etnologiasta tulee kuitenkin varsinaisesti vasta siinä vaiheessa, kun tutkimuksessa käytetään hermeneuttisia käsitteitä, joita myös sovelletaan aineistoa tulkittaessa.

Väärinkäsityksiä hermeneuttisesta kehästä ja ymmärtämisestä nimenomaisina empiirisinä menetelminä on syytä välttää. Me tulkitsemme ja ymmärämme maailmaa joka tapauksessa jollakin tavalla - se on osa ihmisenä olemistamme. Ymmärtäminen ja tulkinta ovat läsnä koko ajan sekä ennen tutkimusta, tutkimuksen aikana että tutkimuksen 
jälkeenkin. Kun kenttäaineistoa kerätään ja siitä aletaan analyysin kautta muodostaa valmista tutkimusta, tarvitaan avuksi tieteenalan omia menetelmiä. Pelkkä tutkittavien sisäisten merkitysten kuvailu ei vie etnologiaa eteenpäin, vaan vuoropuheluun on otettava mukaan tieteentraditio, vertailevat näkemykset ja teoriat. Tässä myös filosofisella hermeneutiikalla on annettavaa etnologeille ja muille kulttuuritieteilijöille: sen kautta on mahdollista saada paitsi teoreettista tukea tutkimusprosessia reflektointiin, myös välineitä toiseuden ja vieraiden kulttuurien kohtaamiseen.

\section{ViITTEeT}

1 Yksi tapa hahmottaa hermeneutiikkaa on määritellä se filosofiseksi suuntaukseksi, jonka ongelmia ovat esimerkiksi tekstin tulkinta, positivismin kritiikki, ymmärtämisen yleiset ehdot ja kielellisyys ymmärtämisen välineenä (Kusch 1986, 12) tai tulkintaopiksi, jota voidaan soveltaa historiallisiin, yhteiskunnallisiin ja kulttuurisiin tutkimuskohteisiin: teksteihin, taideteoksiin, tapahtumiin, puheisiin, toimintoihin ja muihin merkityksiä sisältäviin ilmiöihin (Lönnqvist 1999, 24).

\section{KiRJALLISUUS}

ANTTILA, VEIKKO 1985: Teoreettisia näkökulmia kansatieteeseen. - Pennanen, Jukka \& Sammallahti, Leena \& Haapalainen-Tiainen, Helena (toim.), Teoriaa, aihepiirejä ja näkökulmia kansatieteellisessä tutkimuksessa. Helsinki: Ethnos ry.

BHASKAR, ROY 1979: The Possibility of Naturalism. A Philosophical Critique of the Contemporary Human Sciences. Brighton: The Harvester Press.

DAVIES, CHARLOTTE AULL 1999: Reflexive Ethnography. A Guide to Researching Selves and the Others. London: Routledge.

DILTHEY, WILHELM 1989: Introduction to the Human Sciences. Selected Works Volume 1. Princeton, New Jersey: Princeton University Press.

GADAMER, HANS-GEORG 1988: Truth and Method. London: Sheed and Ward.

GADAMER, HANS-GEORG 2004: Ymmärtämisen kehästä. - Hermeneutiikka. Ymmärtäminen tieteissä ja filosofiassa. Tampere: Vastapaino.

GLASSIE, HENRY 1999: Material Culture. Bloomington and Indianapolis: Indiana University Press.

HEIDEGGER, MARTIN 2000: Oleminen ja aika. Tampere: Vastapaino.

KAJANDER, KONSTA 2012: Vinyylin lämpö. Etnologinen tutkimus musiikinharrastamisesta ja vinyylilevyjen merkityksistä. Etnologian pro gradu -tutkielma. Jyväskylä: Jyväskylän yliopisto.

KAKKORI, LEENA 2012: Maailma Martin Heideggerin filosofiassa. - Kotkavirta, Jussi \& Moisio, Olli-Pekka \& Pihlström, Sami \& Seinälä, Henna (toim.), Maailma. Jyväskylä: Jyväskylän yliopisto. [online]. < https://jyx.jyu.fi/dspace/bitstream/ handle/123456789/37363/978-951-39-4280-9.pdf ? sequence $=1>$ [30.9.2013.] 
Konsta Kajander: Mitä annettavaa filosofisella hermeneutiikalla on etnologialle?

KIRVEENNUMMI, ANNA 1997: Kulttuuri, kansatiede ja kritiikki. Murtumia 1900-luvun lopun tiedonintresseissä ja kulttuurikäsityksessä. - Korhonen, Teppo \& Leimu, Pekka (toim.), Näkökulmia kulttuurin tutkimukseen. Turku: Turun yliopiston täydennyskoulutus.

KUSCH, MARTIN 1986: Ymmärtämisen haaste. Oulu: Pohjoinen.

KUUSELA, PEKKA \& NIIRANEN, VUOKKO (toim.) 2006: Realismin haaste sosiaalitieteissä. Kuopio: Unipress.

LEHTONEN, JUHANI U.E. 2005: Kansatieteen tutkimushistoria. - Korkiakangas, Pirjo \& Olsson, Pia \& Ruotsala, Helena (toim.), Polkuja etnologisiin menetelmiin. Helsinki: Ethnos ry.

LÖNNQVIST, BO 1999: Mitä on etnologia? - Lönnqvist, Bo \& Kiuru, Elina \& Uusitalo, Eeva (toim.), Kulttuurin muuttuvat kasvot. Johdatusta etnologiatieteisiin. Helsinki: SKS

NIINILUOTO, ILKKA 1983: Tieteellinen päättely ja selittäminen. Helsinki: Otava.

NYMAN, HARRI 201 1: Uloimmalla rannalla. Luotsi-ja majakkaperheet asemayhdyskunnissaan. Helsinki: Suomen Muinaismuistoyhdistys.

OESCH, ERNA 2005: Hermeneutiikka tiedonalueiden järjestelmässä - "Sydämen sanasta" ymmärtämisen kehälle. - Tontti, Jarkko (toim.), Tulkinnasta toiseen. Esseitä hermeneutiikasta. Tampere: Vastapaino.

OLLITERVO, SAKARI 2012: Filosofinen hermeneutiikka ja kulttuurihistoria. Nivala, Asko \& Mähkä, Rami (toim.), Tulkinnan polkuja. Turku: Turun yliopisto.

PYYSIÄINEN, ILKKA 2001: Reduktio kielletty! Sortumisvaara! Uskontotieteen perinteet ja reduktionismi. - Tieteessä tapabtuu 5. [online]. <http://www.tieteessatapahtuu.fi/015/pyysiainen.htm > [30.9.2013.]

RAUHALA, LAURI 2005: Ihminen kulttuurissa - kulttuuri ihmisessä. Helsinki: Yliopistopaino.

RICOEUR, PAUL 2000: Tulkinnan teoria. Diskurssi ja merkityksen lisä. Suomentanut Heikki Kujansuu. Helsinki: Tutkijaliitto.

ROLIN, KRISTIINA 2006: Humanistisen ja yhteiskuntatieteellisen tutkimuksen perinteet. - Hallamaa, Jaana \& Launis, Veikko \& Lötjönen, Salla \& Sorvali, Irma (toim.), Etiikkaa ihmistieteille. Helsinki: SKS.

RUOTSALA, HELENA 2005: Matkoja, muistoja, mielikuvia - kansatieteilijä kentällä. - Korkiakangas, Pirjo \& Olsson, Pia \& Ruotsala, Helena (toim.), Polkuja etnologisiin menetelmiin. Helsinki: Ethnos ry.

SÄÄSKILAHTI, NINA 1999: Kansan kulttuurista arkipäivän merkityksiin. - Lönnqvist, Bo \& Kiuru, Elina \& Uusitalo, Eeva (toim.), Kulttuurin muuttuvat kasvot. Johdatusta etnologiatieteisiin. Helsinki: SKS.

TONTTI, JARKKO 2005: Johdanto. - Tontti, Jarkko (toim.), Tulkinnasta toiseen. Esseitä hermeneutiikasta. Tampere: Vastapaino.

VARTO, JUHA 2005: Hermeneutiikka ja historismi. - Tontti, Jarkko (toim.), Tulkinnasta toiseen. Esseitä hermeneutiikasta. Tampere: Vastapaino

VASENKARI, MARIA \& PEKKALA, ARMI 2000: Dialogic Methodology. - Honko, Lauri (ed.), Thick Corpus, Organic Variation and Textuality in Oral Tradition. Helsinki: SKS. 
Konsta Kajander: Mitä annettavaa filosofisella hermeneutiikalla on etnologialle?

VILENIUS, MERJA 2012: Uskonnon alkuperän tutkimuksen historiaa ja nykypäivää - vuoropubelua hermeneuttisen ja kognitiivisen tulkinnan välillä. Helsinki: Books On Demand.

Filosofian maisteri Konsta Kajander on etnologian jatko-opiskelija historian ja etnologian laitoksella Jyväskylän yliopistossa. 